\title{
O DESTINATÁRIO-VISITANTE PRESUMIDO NAS EXPOSIÇÕES DE DIVULGAÇÃO CIENTÍFICA DO CATAVENTO CULTURAL
}

\section{THE PRESUMED RECIPIENT-VISITOR IN THE SCIENTIFIC DIVULGATION EXHIBITION OF CATAVENTO CULTURAL}

\author{
Arlete Machado Fernandes Figashi* \\ Universidade de São Paulo, São Paulo, SP, Brasil
}

\begin{abstract}
Resumo: A teoria dialógica desenvolvida nos trabalhos do Círculo de Bakhtin preconiza que um traço constitutivo do enunciado é seu direcionamento a alguém, ou seja, o fato de estar voltado para seu destinatário, do qual considera pontos de vistas, avaliaç̃oes, visões de mundo, correntes e teorias presumidamente partilhados. Nesse sentido, a orientação do discurso verbal em função de um interlocutor/leitor tem uma imensa importância no processo de sua construção. Essa orientação se materializa nas escolhas estilísticas, composicionais e temáticas e nas entonações valorativas de todo e qualquer enunciado. Desse modo, considerando as reflexões do Círculo bakhtiniano, este trabalho objetiva analisar os enunciados verbo-visuais que compõem as exposições de divulgação científica veiculadas pela instituição Catavento Cultural e Educacional, situada em São Paulo, buscando ressaltar a quem são endereçados os enunciados das exposições e como esse direcionamento se reflete nos elementos essenciais do enunciado expositivo. A análise empreendida revelou que o visitante-destinatário é inscrito de modo distinto a partir da percepção do seu fundo aperceptível de conhecimento pelo autor e da relação desse com o objeto.
\end{abstract}

Palavras-chave: Destinatário presumido; Círculo de Bakhtin; divulgação científica; Catavento Cultural e Educacional; enunciado.

\begin{abstract}
The dialogical theory developed in Bakhtin Circle's works professes that a constitutive property of the utterance is their target to someone, which means the fact of being intended to their recipient, which considers presumably shared points of view, valuations, currents and theories. In that perspective, the course of the verbal discourse in function of an interlocutor/reader assumes a huge relevance in the process of its own construction. This conduction is reified in the stylistic, compositional and thematic choices and in the evaluative intonations of every statement. Thereby, considering the Bakhtin Circle's reflections, this article aims to analyses the verbovisual utterances that composes the exhibitions of scientific dissemination propagated by Catavento Cultural e Educacional institution, located in São Paulo, aiming to emphasize to whom the utterances of the exhibitions are directed and how this targeting is reflected in the essential elements of the expositive utterances. The analysis undertaken revealed that the visitor-recipient is identified in a different way from the perception of his perceivable background of knowledge by the author and his relationship with the object.
\end{abstract}

Keywords: Presumed Recipient; Bakhtin Circle; Scientific Dissemination; Catavento Cultural and Educacional; Utterance.

* Doutora em Letras pela Universidade de São Paulo - USP, São Paulo, SP, Brasil; https://orcid.org/0000-0001-5961-9009; arlete_higashi@hotmail.com

http://dx.doi.org/10.11606/issn.2236-4242.v33i3p221-246 
Linha D’Água (Online), São Paulo, v. 33, n. 3, p. 221-246, set.-dez. 2020

\section{Introdução}

De acordo com o guia Centros e museus de ciência do Brasil, até 2015, o Brasil contava com um total de 268 instituições voltadas à divulgação científica. São 155 no Sudeste; 44, no Sul; 43, no Nordeste; 15, no Centro-Oeste e 11, no Norte. Além dos centros e museus de ciência, foram considerados zoológicos, jardins botânicos, parques e jardins zoobotânicos, aquários, planetários e observatórios. De acordo com a Associação Brasileira de Centros e Museus de Ciência (ABCMC), de 2009 a 2015 houve um aumento de 41\% no número total de instituições, o que, a nosso ver, representa também um crescimento do interesse em promover a ciência para o público mais abrangente.

Tal expansão também tem se refletido nos estudos e pesquisas em torno dos museus e centros de ciência e, por conseguinte, dos aspectos que os constituem. Fundamentadas nas mais diferentes correntes teóricas e sob as mais diversas abordagens metodológicas, as reflexões e as pesquisas, de modo amplo, parecem privilegiar a análise do aspecto educacional presente nas exposições e das especificidades comunicacionais em museus e centros de ciências. Não raros ainda são os estudos que se centram na análise de textos escritos em museus, que geralmente buscam verificar as suas particularidades. Chelini e Lopes (2010) assinalam que a maioria das pesquisas existentes estão voltadas para o exame das explicações de fenômenos ou objetos, ressaltando, de acordo com o tipo de instituição, os diferentes papéis que os textos exercem. Nos museus de arte, apontam as pesquisadoras, o uso de textos é reduzido, porém nos de ciências são largamente utilizados, "não só para a identificação dos espécimes, mas também na explanação de conceitos e interpretação de maquetes e reconstituições" (CHELINI; LOPES, 2010, p. 372). O léxico, as escolhas linguísticas utilizadas, a seleção de informações expostas, o conteúdo explícito e implícito, o nível de compreensão de textos, o percurso de leitura, o comportamento dos visitantes diante dos textos são os elementos analisados por diversos pesquisadores, tanto dentro quanto fora do Brasil (CHELINI; LOPES, 2010). Assim sendo, na visão das autoras, a presença recorrente de textos nos museus de ciências justifica a necessidade de analisá-los, visto que seu uso é um dos principais instrumentos da comunicação museológica. 
Outra perspectiva de estudos em museu e centros de ciências diz respeito ao público visitante desses espaços, denominadas de pesquisas de recepção, que procuram, na visão de Studart et al. (2003), conhecer o público visitante e não-visitante (perfil, gostos, hábitos e características demográficas e socioeconômicas), os padrões de comportamento e interação de diferentes grupos no museu (estudantes, famílias, crianças etc.), as motivações, as expectativas e os ganhos cognitivos e afetivos.

Com vistas a articular os estudos de textos em museus e centros de ciências e os estudos de público, o objetivo principal desse trabalho é realizar uma análise dialógica de enunciados expositivos presentes no Catavento Cultural e Educacional ${ }^{1 .}$

Para tanto, aliamo-nos ao eixo temático do Colóquio Internacional do Grupo de Pesquisa Diálogo (PPG Filologia e Língua Portuguesa, Universidade de São Paulo), PPG Letra (DLM) e UFF (PPG Estudos da Literatura) 90 anos de "Problemas da obra de Dostoiévski (1929-2019)", que discute conceitos formulados nessa obra (polifonia, voz, dialogismo, diálogo, relações dialógicas, palavra/ discurso etc.). Interessa-nos, sobremaneira, um aspecto fundamental das relações dialógicas, objeto da metalinguística proposta em "Problemas da obra de Dostoiévski”, a saber: o destinatário presumido, que trataremos mais adiante.

Assim, com base no pressuposto bakhtiniano de que todo e qualquer enunciado, em maior ou menor agudeza, é sempre direcionado, tem um destinatário de quem espera uma atitude responsiva, elencamos duas perguntas de pesquisa: 1) A quem se dirigem os enunciados expositivos de divulgação científica veiculados no Catavento Cultural e Educacional? 2) De que modo o(s) destinatário(s) presumido(s) influencia $(m)$ a seleção do conteúdo temático, da composição e do estilo dos enunciados expositivos de divulgação cientifica do Catavento Cultural e Educacional? Com isso, verificamos que a seleção dos elementos formadores do gênero exposição de divulgação científica presente no Catavento Cultural e Educacional particulariza-se em função da imagem de um destinatário-visitante dotado de um certo fundo aperceptivo de compreensão responsiva em relação ao objeto de conhecimento exposto. Diante dessa imagem presumida, o falante/escrevente seleciona o conteúdo temático, o estilo e a construção composicional das exposições, nas quais inscreve seu

Esse artigo é um recorte da nossa tese de doutorado intitulada $O$ destinatário inscrito nas exposições de divulgação científica do Catavento Cultural e Educacional, defendida em abril de 2019.

HIGASHI, A. M. F. 0 destinatário-visitante presumido nas exposiç̦oes de divulgação científica do Catavento Cultural 
Linha D’Água (Online), São Paulo, v. 33, n. 3, p. 221-246, set.-dez. 2020

interlocutor por meio de movimentos dialógicos, não apenas com vistas a divulgar os conhecimentos da ciência, mas também a exercer diferentes influências no destinatário-visitante: educativa, de conscientização ambiental, de valorização da esfera científica, de mudança de conduta, de avaliação e concordância em relação aos conhecimentos produzidos pela esfera científica.

Antes de analisarmos os excertos selecionados para esse trabalho, expomos, brevemente, como o destinatário presumido é tratado nas reflexões do Círculo bakhtiniano, bem como apresentamos o Catavento Cultural e Educacional e a seleção dos enunciados expositivos para constituição do corpus e as categorias de análise.

\section{O destinatário sob o enfoque do Círculo de Bakhtin}

Ao percorrermos as obras do Círculo de Bakhtin, observamos que o destinatário ocupa um lugar crucial na teoria dialógica da linguagem. Em muitos de seus textos, o Círculo apresenta como correlatos ao destinatário os termos ouvinte, ouvinte imanente, locutor, público, povo, receptor, leitor, parceiro-interlocutor, contemplador, auditório social e destaca a importância do outro sobre o enunciado e sua conclusibilidade verbal específica. Para assinalar que o Círculo compartilha a ideia de que o enunciado se constrói mediante a presunção de um destinatário real ou hipotético, examinamos alguns textos em que os autores russos refletem acerca da influência reguladora dessa imagem sobre a seleção de todos os elementos do gênero.

Iniciamos pelo texto A palavra na vida e a palavra na poesia: para uma poética sociológica, de Volóchinov (2019[1926]), para quem um enunciado concreto, de qualquer espécie, sempre será um elo de ligação entre sujeitos que conhecem, entendem e avaliam uma situação determinada. Nesse sentido, um enunciado (oral ou escrito), enquanto um todo de sentido, é, segundo o estudioso, composto por duas partes: uma verbalizada e outra subentendida. Então, "a situação integra o enunciado como uma parte necessária da sua composição semântica" (VOLÓCHINOV, 2019[1926], p. 120, grifos do autor).

É importante mencionar que o contexto imediato de que fala o autor pode ser mais ou menos estreito, já que tanto pode estar circunscrito à situação em que ocorre o enunciado, quanto pode se expandir no espaço e no tempo: o presumido

HIGASHI, A. M. F. 0 destinatário-visitante presumido nas exposições de divulgação científica do Catavento Cultural 
pode ser aquele da família, de uma linhagem, da nação, da classe social, dos dias, dos anos ou épocas inteiras (VOLÓCHINOV 2019[1926]). À medida que se amplia o horizonte geral e seu correspondente grupo social, mais constantes se tornam os fatores presumidos em um enunciado. Quando o horizonte é mais amplo, o enunciado pode se sustentar apenas em aspectos constantes e estáveis da vida e em avaliações sociais essenciais e básicas.

Em Marxismo e filosofia da linguagem, Volóchinov (2017 [1929]) apresenta uma abordagem sociológica do interlocutor e também enfatiza a determinação do enunciado em função da sua posição hierárquica:

De fato, não importa qual aspecto da expressão-enunciado consideraremos, ele será definido pelas condições reais do enunciado e, antes de tudo, pela situação mais próxima. Efetivamente, o enunciado se forma entre dois indivíduos socialmente organizados, e, na ausência de um interlocutor real, ele é ocupado, por assim dizer, pela imagem do representante médio daquele grupo social ao qual o falante pertence. A palavra é orientada para o interlocutor, ou seja, é orientada para quem é esse interlocutor: se ele é integrante ou não do mesmo grupo social, se ele se encontra em uma posição superior ou inferior em relação ao interlocutor (em termos hierárquicos), se ele tem ou não laços sociais mais estreitos com o falante (pai, irmão, marido etc.). Não pode haver um interlocutor abstrato, por assim dizer, isolado [...]. Na maioria dos casos, pressupomos um certo borizonte social típico e estável para o qual se orienta a criação ideológica do grupo social e da época a que pertencemos; isto é, para um contemporâneo da nossa literatura, da nossa ciência, da nossa moral, das nossas leis. (VOLÓCHINOV, 2017[1929], p. 204-205, grifos do autor)

Nessa passagem observamos que, se de um lado, a construção do enunciado leva em conta a correlação sócio-hierárquica entre falante e ouvinte, de outro, o contexto mais imediato (e mais amplo) também influencia no projeto discursivo do falante/escrevente, uma vez que ele determina quais serão os destinatários possíveis. Assim, na visão do autor, a situação também motiva a escolha do conteúdo, da forma de composição e do estilo do enunciado, na medida em que as circunstâncias da comunicação discursiva são determinadas pelas condições sociais e econômicas da época (VOLÓCHINOV, 2017 [1929]). Para o autor, a comunicação 
verbal não pode ser entendida e avaliada fora do vínculo com a situação extralinguística, já que é nesse elo que se realiza a interação verbal.

Volóchinov (2019[1930]) postula que a orientação social do enunciado, enquanto dependência do peso sócio-hierárquico do auditório, é um dos efeitos organizadores que, ligado à situação, estabelece não só a forma estilística, mas também a estrutura (gramatical) do enunciado.

É interessante assinalar que, como bem nota Amorim (2001), procurar o destinatário não consiste em apenas revelar um público real ou as coerções reais que determinam um enunciado escrito. "Buscar destinatários é buscar instâncias criadoras. Aqueles que, por oposição ou por acordo, compõem com o autor um diálogo permanente que atravessa o texto e constitui sua tensão de base"(AMORIM, 2001, p. 16-17). A pesquisadora nos revela ainda a necessidade de observar as escolhas do autor no sentido de verificar aqueles a quem ele escolheu e/ou não escolheu responder. Dessa forma, buscar o destinatário inscrito num enunciado significa considerar não apenas aspectos como a posição hierárquica, o gênero, a posição social, a idade e o grau de proximidade entre os sujeitos do discurso, mas também a imagem valorativa que se constrói desse outro e qual(is) resposta(s) são esperada(s).

Em Os gêneros do discurso, Bakhtin (2016[1952-1953]) menciona que, além da imagem do destinatário do enunciado, o falante supõe e antecipa ainda sua reação responsiva (imediata ou de efeito retardado), visto que na relação falante/ ouvinte e escritor/leitor o ato de compreensão não se dá de modo passivo. Ao contrário, o falante espera, de forma ativa, uma resposta, por parte do destinatário, o qual por sua vez

[...] ao perceber e compreender o significado (linguístico) do discurso, ocupa simultaneamente em relação a ele uma ativa posição responsiva: concorda ou discorda dele (total ou parcialmente), completa-o, aplica-o, prepara-se para usá-lo, etc.; essa posição responsiva do ouvinte se forma ao longo de todo o processo de audição e compreensão desde seu início, às vezes literalmente a partir da primeira palavra do falante. (BAKHTIN, 2016[1952-1953], p. 24-25)

De acordo com o teórico russo, as modalidades e concepções de destinatário são determinadas pelo campo de atividade humana, o que significa dizer que esse

HIGASHI, A. M. F. 0 destinatário-visitante presumido nas exposiç̦oes de divulgação científica do Catavento Cultural 
outro pode ser desde um participante-interlocutor direto do diálogo cotidiano até uma coletividade de algum campo especial da comunicação cultural, ou um outro presumido, tal como pretendemos assinalar nas nossas análises. É essa concepção, mesmo que virtual, que determina o conteúdo temático, o estilo e a composição do enunciado, já que todo gênero discursivo tem sua compreensão de destinatário. Nas palavras de Bakhtin,

Ao falar sempre levo em conta o fundo aperceptível da percepção do meu discurso pelo destinatário: até que ponto ele está a par da situação, dispõe de conhecimentos especiais de um dado campo cultural da comunicação; levo em conta as suas concepções e convicções, seus preconceitos (do meu ponto de vista), as suas simpatias e antipatias - tudo isso irá determinar a ativa compreensão responsiva do meu enunciado por ele. Essa consideração irá determinar também a escolha do gênero do enunciado e as escolhas dos procedimentos composicionais e, por último, dos meios linguísticos, isto é, o estilo do enunciado. Por exemplo, os gêneros da literatura popular científica são endereçados a um determinado círculo de leitores dotados de um determinado fundo aperceptível de compreensão responsiva; a outro leitor está endereçada uma literatura didática especial e a outro, inteiramente diferente, trabalhos especiais de pesquisa. Em todos esses casos, a consideração do destinatário (e do seu campo aperceptível) e sua influência sobre a construção do enunciado são muito simples. Tudo se resume ao volume dos seus conhecimentos especiais. (BAKHTIN, 2016[1952-1953], p. 63-64)

Essas afirmações mostram-se muito pertinentes para os fins do nosso trabalho, pois reforçam a hipótese de que o projeto discursivo das exposições de divulgação científica do Catavento Cultural percebe em maior ou menor grau um destinatário pressuposto e seu fundo aperceptivo, de quem também se espera um posicionamento responsivo específico. De acordo com o autor russo, é sobre esse fundo aperceptivo, enquanto vivências internas dos destinatários, que está direcionado qualquer enunciado. Na perspectiva bakhtiniana, mesmo as formas de exposição científica são influenciadas pela concepção de destinatário, o qual se materializa na seleção dos meios linguísticos para exprimir o endereçamento: recursos lexicais, morfológicos (pronomes, formas pessoais dos verbos), sintáticos (diversos padrões e modificações das orações) e nos elementos pictóricos.

HIGASHI, A. M. F. 0 destinatário-visitante presumido nas exposições de divulgação científica do Catavento Cultural 
Linha D'Água (Online), São Paulo, v. 33, n. 3, p. 221-246, set.-dez. 2020

Em O texto na linguistica, na filologia e em outras ciências humanas, de Bakhtin (1959-1961), percebemos em diversas passagens a afirmação de que o outro tem uma imensa importância no processo de interação verbal, na medida em que o enunciado é considerado como uma unidade real da comunicação discursiva e é, então, o produto das relações estabelecidas entre interlocutores, que se alternam nos papéis de falante/escrevente/destinador e ouvinte/leitor/destinatário.

A existência e a alternância entre o eu e o outro, decorrente da interação verbal, constituem as condições para que surjam as relações dialógicas, na medida em que elas só são possíveis entre enunciados integrais de diferentes sujeitos do discurso (reais ou potenciais) inseridos em contextos sociais e históricos: "É precisamente essa comunicação dialógica que constitui o verdadeiro campo da vida da linguagem" (BAKHTIN, 2008 [1963], p. 209). E toda comunicação dialógica pressupõe um eu que adequa sua fala (oral ou escrita) para a imagem presumida de um outro, ou seja, para um destinatário com quem estabelece uma interação.

Em síntese, para a teoria dialógica do Círculo, cada palavra implica uma concepção singular do ouvinte e seu fundo aperceptivo, para o qual está orientada toda e qualquer enunciação. E é sobre essa concepção que nossa análise incidirá; mas, antes, apresentamos a instituição que abriga os enunciados expositivos analisados, a constituição do corpus e os critérios de análise.

\section{Catavento Cultural e Educacional}

O Catavento Cultural e Educacional, inaugurado em 2009, é uma associação de direito privado, sem fins lucrativos e econômicos, que, segundo o Estatuto Social da entidade, opera para estimular o desenvolvimento sociocultural da população do Estado de São Paulo.

Segundo o site da instituição, é considerado como um dos museus mais visitados do Estado de São Paulo, e o espaço conta com mais de 250 exposições distribuídas em 8.000 metros divididos em quatro grandes seções temáticas: Universo, Vida, Engenho e Sociedade. Na seção Universo, que contou com a colaboração técnica e material do Instituto de Astronomia Geofísica e Ciência Atmosférica da USP, o acervo está distribuído em 3 módulos: Astronomia, Aventura no sistema solar 
e Terra. A Vida apresenta quatro grandes divisões, a saber: Borboletário, (com a instalação Borboletário); Do Macaco ao homem, Viagem pelo fundo do mar (com a instalação Submarino) e, por fim, a Vida (constituída pelas exposições Aquários marinhos, Árvore da vida, Aves do Brasil, Célula e DNA, Corpo humano, Do veneno ao remédio, Evolução e Darwin, Fotossíntese, Insetos, Vida no oceano). A seção Engenho abrange dois módulos: Engenho e Se liga no lego. O primeiro é formado pela exposição de experimentos que divulgam saberes a respeito do calor, do eletromagnetismo, dos fluídos, da luz e da óptica, da mecânica e do som, os quais podem ser manipulados pelos visitantes-destinatários. $\mathrm{O}$ segundo, Se liga no lego, é composto por kits da Lego Education que são disponibilizados para montagem sob orientação de monitores. Por fim, localizada no pavimento superior do prédio, a seção Sociedade foca diferentes temáticas, as quais estão distribuídas em seis módulos, a saber: Alertas, Ecologia, Estúdio de TV; Jogos do poder Laboratório de química, Matéria e Nanotecnologia. De modo amplo, o destinatáriovisitante poderá ter contato com saberes sobre os recursos naturais da Terra e sua preservação, o uso da química na esfera cotidiana, drogas lícitas e ilícitas, política, arte, nanotecnologia, tecnologia, fatos históricos e sustentabilidade.

Isto posto, é importante mencionar que diante da amplitude da instituição descrita acima, o exame de todas as suas unidades expositivas se mostra, nos limites desse trabalho, uma tarefa impraticável. Nesse sentido, fez-se necessário eleger critérios para justificar a escolha do corpus, tarefa que passamos a delinear abaixo.

\section{Seleção dos enunciados expositivos para constituição do corpus e categorias de análise}

Ao nos debruçarmos sobre o material de análise, procuramos eleger critérios de seleção que não apenas delimitassem o nosso corpus, mas que também pudessem revelar as regularidades que permeiam o projeto discursivo das exposições selecionadas. Vale lembrar que, como bem afirmou Bakhtin (2016[1952-1953]), o projeto ou a intenção discursiva do falante regula tanto a escolha do objeto, seus limites e a sua exauribilidade temática, quanto a escolha da forma do gênero de discurso, a qual "é determinada pela especificidade de um dado campo da comunicação 
discursiva, por considerações semântico-objetais (temáticas), pela situação concreta da comunicação, pela composição pessoal de seus participantes, etc." (BAKHTIN, 2016[1952-1953], p. 38).

Nesse sentido, durante nossas constantes visitas ao Catavento, observamos que a intenção discursiva do falante (que consideramos, amplamente, como um autor/falante institucionalizado) se materializa em recursos expográficos diversos (painéis, réplicas, maquetes, fotos, experimentos manipuláveis, filmes, hipertextos, aparelhos audiovisuais, microscópicos, monóculos), os quais, combinados ou não, de modo geral, constituem o todo de cada exposição. Dentre esses recursos, constatamos que, na instituição acima, muitas exposições são compostas por painéis verbo-visuais, o que nos motivou a considerá-lo um bom material analítico. Assim, a escolha pelos painéis em detrimento de outros elementos que compõem a totalidade das exposições se justifica por duas razões: primeira, pela sua regularidade nas seções do Catavento; segunda, pela sua materialidade, uma vez que os painéis são compostos por enunciados verbais e visuais, objetos privilegiados para a análise enunciativo-dialógica que empreendemos nestE trabalho, ou seja, tomando emprestadas as palavras de Bakhtin (2016[1959-61], P. 87), "estamos interessados primordialmente nas formas concretas dos textos e nas condições concretas da vida dos textos, na sua inter-relação e interação".

Dessa forma, dentre as sete exposições analisadas em nossa tese de doutorado, selecionamos duas, a saber: Corpo Humano, da seção Vida, e Ecologia, da seção Sociedade, por apresentarem uma extensão analítica compatível com este artigo.

Com base nas perguntas acima expostas, voltamo-nos para as singularidades verbais e visuais de todas as exposições da instituição e verificamos que a inscrição do destinatário-visitante se dá por meio de dois movimentos dialógicos, identificados a partir da teoria bakhtiniana: pelo diálogo aberto e pelo diálogo velado com o destinatário-visitante.

O diálogo aberto com o destinatário-visitante pôde ser verificado mediante duas categorias: 1) endereçamento mais direto entre o falante e o destinatário-visitante presumido; 2) a imagem hipotética do fundo aperceptivo do destinatáriovisitante. O diálogo velado pôde ser constatado por outras duas categorias: 1) o 
apagamento do endereçamento direto entre o falante e o destinatário-visitante; 2) a diretriz voltada para o objeto de discurso.

No primeiro movimento, o enunciado expositivo apresenta, para usar os termos de Bakhtin (2016[1950]), um apelo ao diálogo, à sensação e à imagem imediata de ter um ouvinte, levando em conta suas opiniões, gostos, apreciações e, sobretudo, o seu fundo aperceptivo de percepção. Nesse caso, o estilo prosaico torna-se um dos aspectos mais marcantes e se presta a estabelecer um diálogo mais estreito com o destinatário-visitante.

Já no segundo, observa-se um enfraquecimento desse apelo. Nesse caso, não estamos afirmando a inexistência de um direcionamento do enunciado, visto que esse sempre pressupõe um destinatário definido, é dialógico. No entanto, admitese que, em certas exposições, a diretriz do enunciado expositivo parece estar mais centrada no seu objeto de dizer, a realidade científica, não sendo "desviado dessa concentração pela interferência real ou presumida do outro (pelo ponto de vista do outro, pela discordância do outro, etc.)" (BAKHTIN (2016[1950], p. 123). Essas especificidades são, na visão de Bakhtin, características do discurso monológico (não absoluto), no qual o destinatário tem uma natureza mais indefinida e coletiva.

Para os fins deste artigo, selecionaremos um recorte de cada movimento, cujo foco analítico do material incidirá sobre os elementos que constituem a exposição: o conteúdo temático, a construção composicional e o estilo, verificando a imagem do destinatário-visitante neles inscrita.

\section{O diálogo aberto com o destinatário-visitante presumido}

Nesta seção, apresentamos a análise dos enunciados expositivos que estabelecem um direcionamento mais aberto com o destinatário-visitante, aspecto discursivamente marcado nos aspectos estilísticos, temáticos e composicionais que compõem a totalidade das exposições. O objetivo é examinar como se dá a influência do outro na seleção desses elementos e as ênfases valorativas que derivam da relação entre destinador-Catavento e destinatário-visitante. 
Antes de prosseguirmos com a nossa análise, é importante mencionar que, a nosso ver, a exposição Corpo Humano ${ }^{2}$ está organizada em três articulações composicionais. A primeira está disposta em painéis no salão principal e apresenta conhecimentos sobre os sentidos, os músculos e o esqueleto; a outra, que trata da respiração, reprodução humana, circulação, sistema nervoso e digestão, está locada numa sala contígua à mesma seção; e a terceira, localizada no andar superior dessa adjacente, é composta por uma maquete gigante que simula o interior do intestino.

Como nosso objeto de análise são os enunciados verbo-visuais, analisaremos os materiais dispostos nos painéis do salão principal e da sala contígua. De modo geral, a exposição Corpo Humano se organiza de modo a estreitar as relações com o destinatário presumido, por meio de determinadas escolhas temáticas, estilísticas e composicionais que podem indicar o visitante em potencial.

Ao nos voltarmos, de modo pontual, para os elementos estilísticos da exposição ora analisada, assinalamos que o par pergunta-resposta é a escolha linguística mais marcante para estabelecer uma relação dialógica com o visitante, configurando uma estabilidade relativa e distintiva no projeto discursivo do falante.

A partir da lógica constituída por Bakhtin (2016[1952-1953], as réplicas só são possíveis entre enunciados de diferentes sujeitos do discurso. Transpondo esse fundamento para nossa análise, entendemos que o falante (institucional), ao trazer a questão e respondê-la ele mesmo, determina, virtualmente, um outro que se posicionaria responsivamente de modo específico ante o questionamento imposto nos painéis, ou seja, concebe não apenas o seu destinatário em potencial, mas também a sua réplica interior. Diante disso, geralmente, quando o falante faz uma pergunta para seu interlocutor, ele imagina que o outro saiba a resposta, do contrário, certamente, não a faria. No entanto, nos enunciados expositivos, vemos um movimento oposto, no sentido de que o falante prevê que seu interlocutor não tem a resposta

2 O Plano estratégico de atuação da Catavento Cultural e Educacional para gestão do museu Catavento - Espaço Cultural de ciência no período de 2017-2022 assim divide a exposição: "Humanos: Nesta área reunimos informações sobre os humanos, seus sistemas fundamentais, sentidos, músculos e esqueleto. O Homem Virtual teve em sua concepção parceria com o Projeto Homem Virtual da Faculdade de Medicina da USP. Na sala do corpo humano o sistema nervoso, digestório, respiratório, circulatório e reprodutor podem (sic!) ser entendidos com facilidade" (p. 14). É importante mencionarmos que a primeira parte da exposição ora analisada sofreu uma reformulação em 2016.

HIGASHI, A. M. F. 0 destinatário-visitante presumido nas exposições de divulgação cientíifica do Catavento Cultural 
Linha D'Água (Online), São Paulo, v. 33, n. 3, p. 221-246, set.-dez. 2020

para aquilo que se questiona, uma vez que o texto que compõe o painel já antecipa a resposta para a questão apresentada, conforme pode ser identificado na figura abaixo:

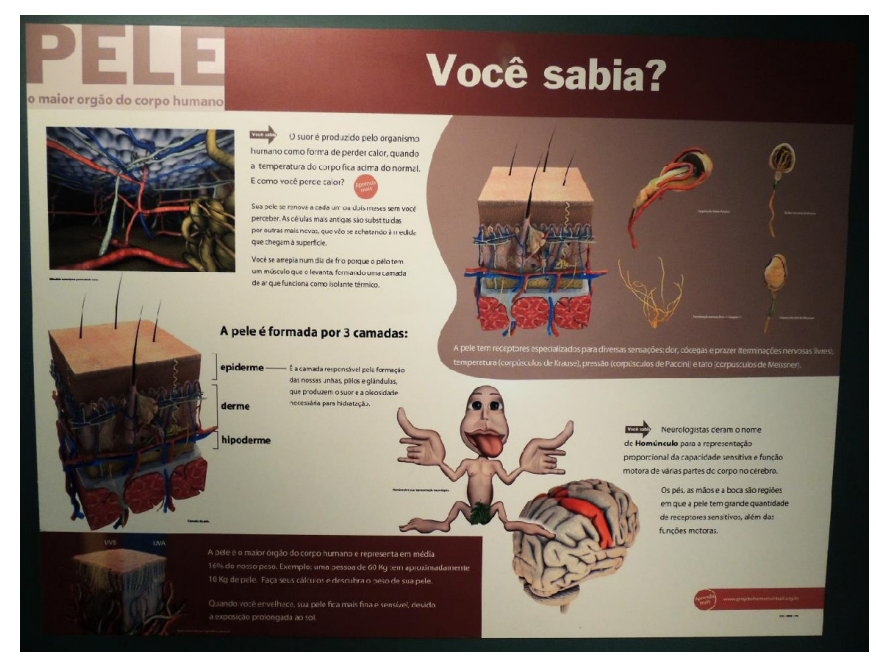

Fig. 1: Painel Pele

Fonte: Arlete Higashi, jun. 2016

E quando essa pressuposição se dá de forma inversa, o questionamento não é explicitamente respondido, cabendo ao visitante-destinatário depreender a resposta a partir dos seus conhecimentos prévios, conforme podemos visualizar na figura 2:

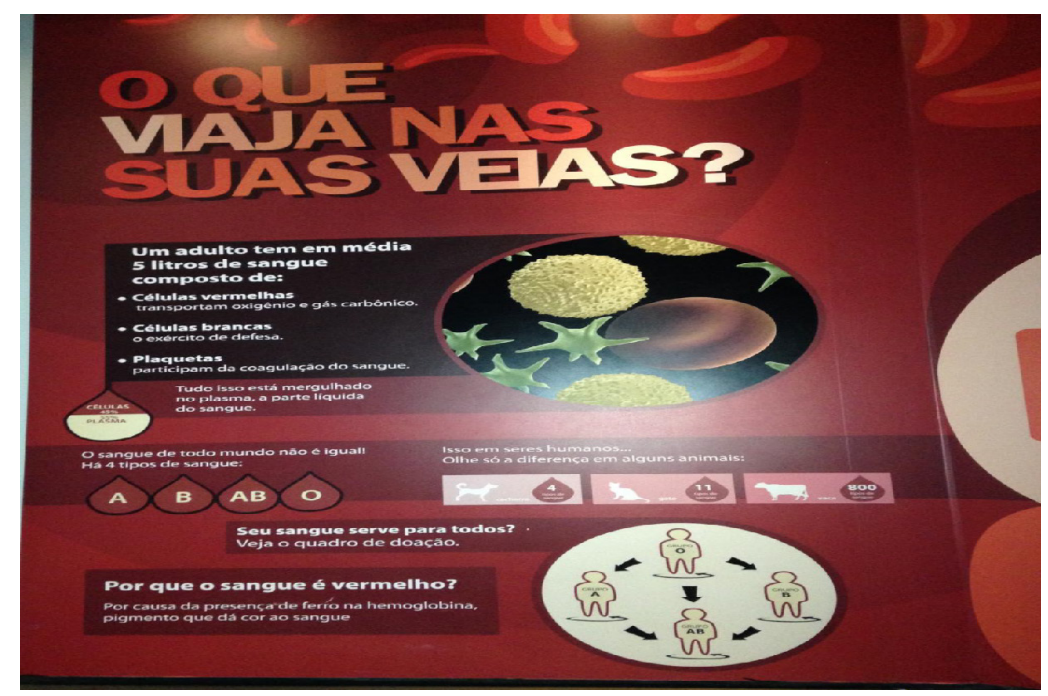

Fig. 2: Trecho do painel $\mathrm{O}$ que viaja nas suas veias?

Fonte: Arlete Higashi, fev. 2015

HIGASHI, A. M. F. 0 destinatário-visitante presumido nas exposiç̦oes de divulgação científica do Catavento Cultural 
No excerto, observamos que o que introduz os assuntos apresentados é a pergunta “o que viaja nas suas veias?", no entanto, antecipando que o interlocutor (visitante) tenha algum conhecimento pré-estabelecido sobre o assunto, os enunciados que se seguem não respondem explicitamente à indagação proposta e apresentam informações gerais sobre elementos do sangue. Aqui, aquele que questiona parece testar o conhecimento anterior do outro. Assim, pode-se inferir que, nesse caso, o par dialógico pergunta-resposta configura-se como um procedimento linguístico de transmissão dos saberes da ciência, a qual inscreve um destinatáriovisitante com um fundo aperceptível variável de conhecimento (ora destinatáriovisitante não o tem, ora o tem parcialmente). Essa ideia é reforçada no rodapé dos painéis da exposição Corpo Humano, no qual se pode ler a sentença imperativa "aprenda mais", sugerindo um convite para o visitante expandir o conhecimento no site do Projeto Homem virtual, onde pode obter informações complementares, direcionando-se, então, a um destinatário-visitante em construção. Isso confirma o que destacou Bakhtin 2016(1952-53): o volume dos conhecimentos especiais do destinatário é decisivo para a construção do enunciado. Desse modo, essa presunção regula a forma, o conteúdo e o estilo dos enunciados expositivos de divulgação da ciência que são apresentados aos visitantes.

Dito de outro modo, a nosso ver, o gênero pergunta-resposta, típico das modalidades discursivas orais, mas também muito usual em contextos de ensino-aprendizagem e nos textos de divulgação científica para o público não-especialista, funciona como um introdutor das explicações que se seguem e como um indicador da pressuposição do falante em relação às vivências anteriores do seu interlocutor. A imagem desse destinatário-visitante orienta não apenas a constituição do enunciado expositivo como um todo, mas também a seleção dos assuntos tratados, uma vez que julga quais saberes da ciência podem ou não fazer parte dos conhecimentos por ele acumulados. Afinal, como Bakhtin (2016-1952-53]) assevera, ao construir o enunciado, o falante procura definir seu auditório de maneira ativa, mas, ao mesmo tempo, também busca antecipar suas possíveis respostas.

Ainda no que refere ao estilo da dimensão verbal, é possível depreender nos painéis expositivos outros recursos estilísticos que foram selecionados em função da imagem do destinatário-visitante, como observamos nos recortes 3 e 4 : 
Linha D’Água (Online), São Paulo, v. 33, n. 3, p. 221-246, set.-dez. 2020

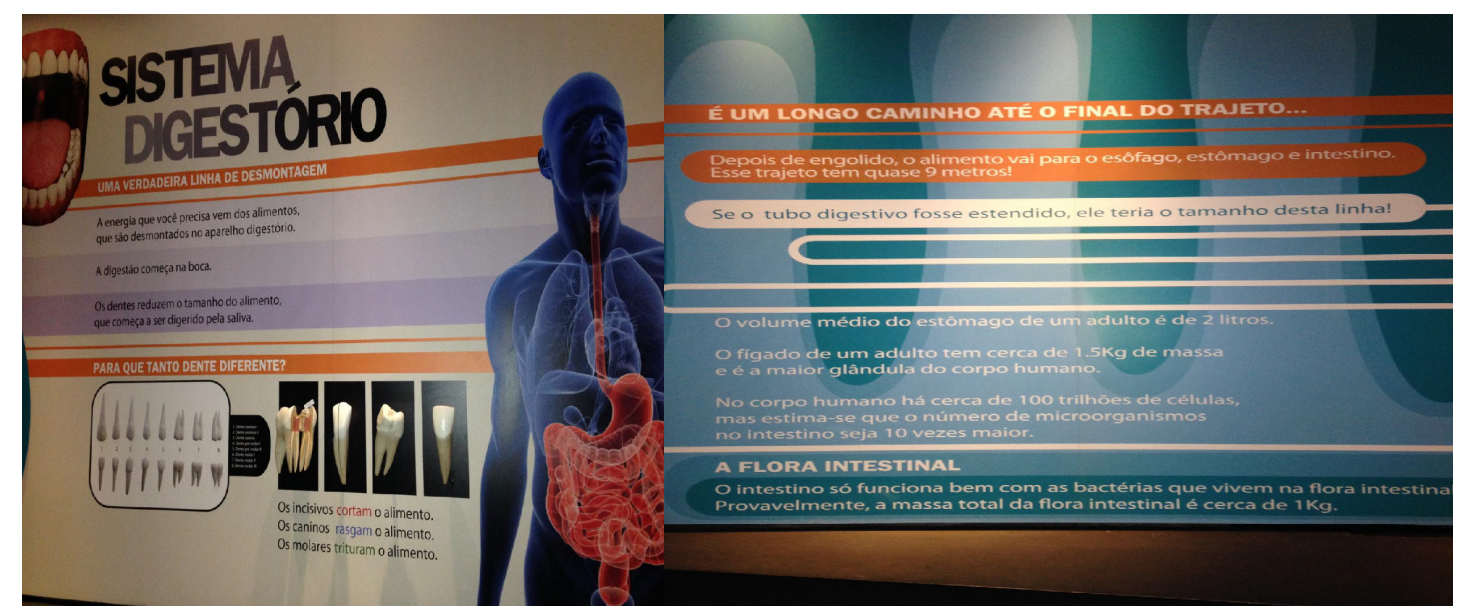

Fig. 3: Trecho do painel Sistema Digestório / Fig. 4: Trecho do painel Sistema respiratório

Fonte: Arlete Higashi, fev. 2015

Os recortes das figuras exemplificam os recursos estilísticos mais recorrentes da exposição: o predomínio do tempo presente do indicativo, como forma de sugerir algo categórico e atual (precisa, começa, reduzem, cortam, rasgam, trituram); da linguagem simples e de períodos curtos, com vistas a facilitar a leitura do destinatário presumido, no sentido de que ele tenha uma compreensão ativa e responsiva daquilo que lê (a digestão começa na boca/os incisivos cortam o alimento/os caninos rasgam o alimento/os molares trituram o alimento); de explicações (a energia que você precisa vem dos alimentos, que são desmontados no aparelho digestório); de descrições (o fígado de um adulto tem cerca de $1,5 \mathrm{~kg}$ de massa) e de metáforas (uma verdadeira linha de desmontagem/exército de defesa).

Outro elemento linguístico que chama a atenção é a presença maciça de pronomes, pessoais (você/[nós]) e possessivos (seu/sua), os quais simulam a representação do falante e do ouvinte inseridos em um contexto de diálogo. No caso específico dos enunciados expositivos analisados, o uso de pronomes (você/seu/sua/ [nós]) reflete, aproveitando as ideias de Bakhtin (2016[1950]), a interação entre os falantes ou como forma de relação dialógica da comunicação discursiva (cotidiana). Mas, essa relação de proximidade entre falante e destinatário, construída pelos recursos linguísticos, parece não se refletir na dimensão visual da exposição, uma vez que as imagens apresentam uma menor liberdade estilística, atrelando-se mais às ilustrações usadas em livros didáticos de ciências, atlas ou enciclopédias. Talvez isso se explique pelo viés autoral, já que a exposição foi concebida em parceria com

HIGASHI, A. M. F. 0 destinatário-visitante presumido nas exposições de divulgação científica do Catavento Cultural 
Linha D’Água (Online), São Paulo, v. 33, n. 3, p. 221-246, set.-dez. 2020

Projeto Homem Virtual, da Faculdade de Medicina da USP, o que implica seguir um maior rigor científico em relação às escolhas estilísticas para sua produção. Assim, as imagens aproximam-se mais das ilustrações de caráter científico e têm seus sentidos dependentes da dimensão verbal, uma vez que isoladamente são difíceis de serem interpretadas pelo visitante.

Arriscamo-nos a dizer, então, que existe, na exposição ora analisada, uma certa tensão entre a dimensão verbal e a visual, uma vez que a primeira, antecipando e respondendo as réplicas de um visitante-destinatário em construção, lança mão de escolhas estilísticas e composicionais condizentes com tal imagem, enquanto a segunda, mais restrita às convenções da ciência e da ilustração científica, mostra-se mais estandardizada. Não estamos afirmando que existe uma divergência dialógica entre essas dimensões em termos de conteúdo, apenas destacamos que a inscrição do destinatáriovisitante se dá de modo mais contundente na dimensão verbal da exposição.

Levando em conta o exposto até aqui, entendemos que o conteúdo temático se revelava na presunção do universo de interesse do destinatário-visitante em potencial: o conhecimento da anatomia humana pelo viés da ciência como condição para manutenção da saúde corporal.

\section{O diálogo velado com o destinatário-visitante}

Aliada às análises da seção anterior, observaremos, no segundo movimento dialógico, a inscrição do destinatário-visitante nos três elementos que compõem a exposição Ecologia, da seção Sociedade: a construção composicional, o conteúdo temático e o estilo, conforme verificaremos mais abaixo.

A disposição e a divisão do material verbal e visual nos painéis expositivos são recorrentes: blocos de parágrafos curtos e conjugados com imagens, os quais podem ser lidos de modo linear ou não. A nosso ver, na exposição Ecologia, "a percepção do ouvinte e do leitor, bem como das suas reações possíveis, fundamenta a divisão do discurso em partes, que na linguagem escrita, são designados parágrafos" (VOLÓCHINOV (2017 [1929], p. 244), uma vez que o falante parece prever a situação de leitura pela qual o visitante-destinatário está exposto: em pé, sujeito a interferências distintas. Presume-se, assim, pelo contexto discursivo, 
Linha D’Água (Online), São Paulo, v. 33, n. 3, p. 221-246, set.-dez. 2020

que textos demasiadamente extensos e com períodos complexos poderão, pelas circunstâncias, reprimir a atenção do visitante em potencial. No que se refere às especificidades dos elementos verbais que constituem o todo enunciativo da exposição, verificamos que a seleção dos recursos estilísticos é mais afetada pela relação valorativa do autor com o objeto do seu enunciado, no sentido de que

A escolha dos meios linguísticos e dos gêneros do discurso é determinada, primeiramente, pelas tarefas (pela ideia) do sujeito do discurso (ou autor) centradas no objeto e no sentido. É o primeiro elemento do enunciado que determina as suas peculiaridades estilístico-composicionais. $\mathrm{O}$ segundo elemento do enunciado, que the determina a composição e o estilo, é o elemento expressivo, isto é, a relação subjetiva emocionalmente valorativa do falante com o conteúdo do objetivo e do sentido do enunciado. (BAKHTIN, 2016[1952-1953], p. 47, grifos do autor)

É nesse sentido que analisamos a exposição Ecologia. Cremos que todas as palavras que constituem o enunciado expositivo estão, primordialmente, voltadas para o objeto, mas "reagem ao mesmo tempo e intensamente à palavra do outro, correspondendo-lhe e antecipando-a" (BAKHTIN, 2008[1963], p. 225).

Assim, prevalecem, no âmbito das dimensões verbal e visual, escolhas estilísticas que colocam em relevo o conteúdo temático da exposição, o qual é, ao mesmo tempo, o seu objeto: o discurso ideológico de educação ambiental, com viés nacionalista, aliado à valoração do empenho dos cientistas ou do campo da ciência para reverter a degradação das "Maravilhas da Terra", para usar um termo da própria exposição. Tudo isso compõe os textos e as imagens que constituem o todo do enunciado expositivo. Nos textos escritos, o nacionalismo se presentifica pelo uso abundante de adjetivos, os quais não se prestam apenas à caracterização e à descrição da fauna e da flora, mas, sobretudo, à qualificação distintiva do ecossistema brasileiro, como mostram os termos em itálico:

Viés nacionalista: painel Peixe-Boi - O peixe-boi marinho foi um dos primeiros animais da nossa fauna a ser avistado pelos navegadores portugueses/ $\mathrm{O}$ pequeno mico-leão dourado, uma espécie de macaco exclusivo da Mata Atlântica, quase desapareceu para sempre da natureza/O Brasil é um país de grande biodiversidade.

HIGASHI, A. M. F. 0 destinatário-visitante presumido nas exposiç̦oes de divulgação científica do Catavento Cultural 
Linha D’Água (Online), São Paulo, v. 33, n. 3, p. 221-246, set.-dez. 2020

Painel Reservas Extrativistas: Nosso potencial de crescimento é também muito grande.

Painel América do Sul: Em virtude de abranger várias latitudes, os cenários podem ser muito diferentes. Os mais impressionantes são o Rio Amazonas e sua grande planície, constituindo a incrivel Floresta Amazônica [...]

Depreendemos que o viés nacionalista se materializa no conjunto lexical de opulência da natureza e da sociedade distintivos em relação a outros países, o que pode ser verificado nos adjetivos que inserem um tom de "apreciação" ou "intensificação" (CASTILHO 3 , 2010): grande biodiversidade; exclusivo da mata atlântica; grande planície; incrivel Floresta Amazônica; Nosso potencial de crescimento é também muito grande; os mais impressionantes, por exemplo, que não apenas refletem os “ gostos sociais e o de cultura do interlocutor ou do escritor", mas também uma expressividade que revela e exalta uma identidade brasileira. $\mathrm{O}$ conhecimento científico limita-se aqui ao recorte e à unificação de elementos do horizonte social que contribuem para a criação uma certa hegemonia nacional.

Já a valorização da esfera da ciência e de seus agentes se materializa numa espécie de narração, entendida, nos termos de Castilho (2010), como uma enumeração de eventos que aqui se estrutura em dois planos: o da situação e o da ação, como mostra a transcrição abaixo:

Plano de situação: Painel Peixe-Boi - Em 1500, os peixes-bois (sic!) já eram caçados pelos índios e passaram a ser cobiçados também pelos colonizadores europeus recém-chegados ao Brasil, pois esses logo descobriram as boas propriedades da carne, da gordura e do couro desse mamífero. $\mathrm{O}$ fato de ser grande, dócil e vir à tona para respirar tornava fácil a sua captura. A caça comercial indiscriminada do peixe-boi seguiu intensa por séculos e colocou a espécie em risco de extinção.

Plano de ação: Esse quadro só começa a mudar com o projeto Peixe-Boi em 1980, criado para estudar e proteger os últimos 500 indivíduos remanescentes [...].

3 Ataliba Teixeira Castilho (2010) propõe que o discurso "inclui o locutor, o interlocutor, o assunto e a rede imagens que os falantes constituem a respeito deles mesmos e de suas pressupostas posições com respeito ao assunto" (p. 134), elementos que dialogam com os preceitos do Círculo e justificam nossa escolha pelo autor.

HIGASHI, A. M. F. 0 destinatário-visitante presumido nas exposiçōes de divulgaccão cientifica do Catavento Cultural 
Mico-leão-dourado - Plano de situação: O pequeno mico-leão dourado, uma espécie de macaco exclusiva da Mata Atlântica, quase desapareceu para sempre da natureza. Em 1960, apenas 200 deles ainda viviam soltos na mata, nas proximidades de Casimiro de Abreu (RJ) e estavam cada vez mais encurralados pelo desmatamento, queimadas e captura para venda ilegal.

Plano de ação: O fim parecia uma questão de tempo. E seria mesmo, não fosse o aparecimento de um grupo de pesquisadores dispostos a trabalhar para evitar a extinção dessa espécie. O principal plano dos cientistas era trazer de volta para a mata atlântica os micos-leões espalhados por zoológicos do mundo inteiro. $\mathrm{Na}$ época poucos acreditavam no plano. Mas hoje, 22 anos após o início do projeto, os resultados são excelentes.

Vemos que o plano da situação busca mostrar como o homem tem atuado no ecossistema, enquanto o da ação destaca como o país e, sobretudo, seus cientistas, têm trabalhado para reverter a degradação do meio ambiente ocasionada pelo ser humano. Diante disso, o enunciador seleciona palavras e construções sintáticas que produzem uma avaliação social de magnitude da esfera da ciência, com destaque para o papel dos seus agentes, que, nesse discurso, parecem ganhar status de super-heróis que lutam pela transformação de uma determinada realidade: "O fim parecia uma questão de tempo", "não fosse o aparecimento de um grupo de pesquisadores dispostos a trabalhar para evitar a extinção", "O principal plano dos cientistas era trazer de volta para a mata atlântica os micos-leões espalhados por zoológicos do mundo inteiro", "poucos acreditavam no plano", "cientistas fazem projeções do clima futuro", "os cientistas são capazes de determinar, com uma boa precisão a temperatura e a composição da atmosfera”. Embora esses enunciados estejam dispersos em diferentes pontos da exposição, é possível depreender, na totalidade do discurso, um tom heroico ligado às ações e ao empenho dos cientistas que dispõem de "argumentos, experiência, experimentos" capazes de mudar uma determinada realidade social. Cremos que o viés nacionalista e a valoração do empenho dos cientistas/campo da ciência formam também o fundo entonacional da exposição, o qual parece estar voltado para seu objeto de dizer.

$\mathrm{Na}$ exposição Ecologia, aparentemente, o enunciado não se desvia da concentração no aspecto emocional do discurso pela interferência presumida do outro.

HIGASHI, A. M. F. 0 destinatário-visitante presumido nas exposiç̦oes de divulgação científica do Catavento Cultural 
Linha D’Água (Online), São Paulo, v. 33, n. 3, p. 221-246, set.-dez. 2020

Essa concentração parece remeter o discurso expositivo à categoria de monólogo mencionado por Bakhtin (2016[1950]) no texto Diálogo I, onde destaca:

No discurso monológico, o ouvinte tem um caráter mais indefinido e coletivo (embora esse "coletivo" possa ser sentido de modo diferenciado: amigos-correligionários, inimigos-adversários, etc.). O principal é que o monólogo exclui a interferência do ouvinte nos momentos decisivos do discurso, o ouvinte pode reagir apenas à totalidade do monólogo, e assim mesmo só à revelia. Quem escolhe a forma monológica ganha o direito a uma concentração excepcional no objeto de seu discurso e na sua relação com este, o direito a certa independência em face do ouvinte, à recusa de voltar-se para ele (BAKHTIN, 2016[1950], p. 123).

No entanto, ainda que essa certa independência seja real, como também nos alertou a teoria bakhtiniana, sabemos que esse monologismo é relativo, uma vez que a escolha de todos os recursos linguísticos é feita sob maior ou menor influência do destinatário, das suas vozes e da sua resposta antecipada.

Nessa exposição, a responsividade atrela-se à ideia de responsabilidade social atribuída ao visitante-destinatário presumido, a qual é também imageticamente ilustrada na metáfora visual da mão na posição de concha, carregando uma árvore que participa da construção de sentido do enunciado: a revelação profética de que a situação do planeta está nas mãos do espectador. Conforme vemos na figura 5:

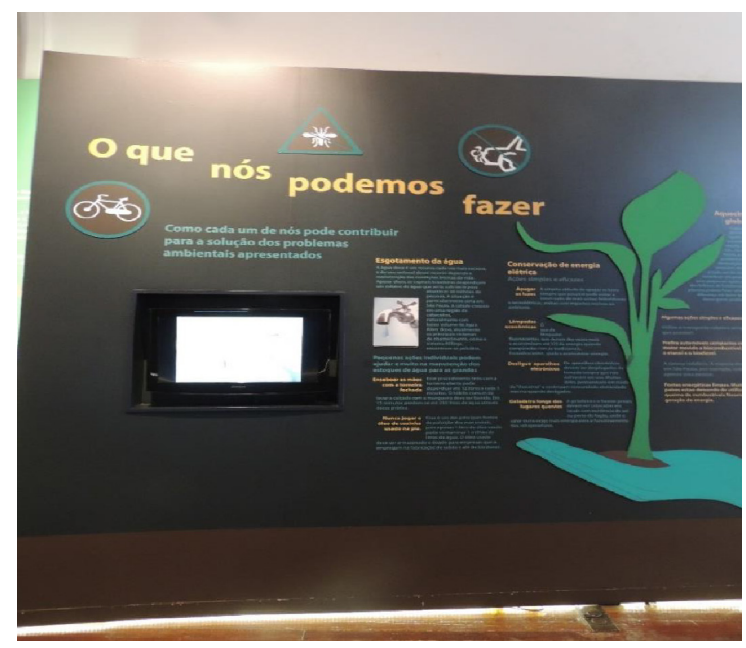

Figura 5: Painel $\mathrm{O}$ que nós podemos fazer Fonte: Arlete Higashi, jun. 2016

HIGASHI, A. M. F. 0 destinatário-visitante presumido nas exposiç̦oes de divulgação científica do Catavento Cultural 
Linha D’Água (Online), São Paulo, v. 33, n. 3, p. 221-246, set.-dez. 2020

Em relação às imagens que acompanham os textos, verificamos que suas principais funções são ora explicar e quantificar fenômenos, ora ilustrar, ora construir um cronotopo. Para atingir esses objetivos, o falante seleciona, principalmente, cinco tipos de imagens: fotografia, mapa, gráfico, esquema e desenho:

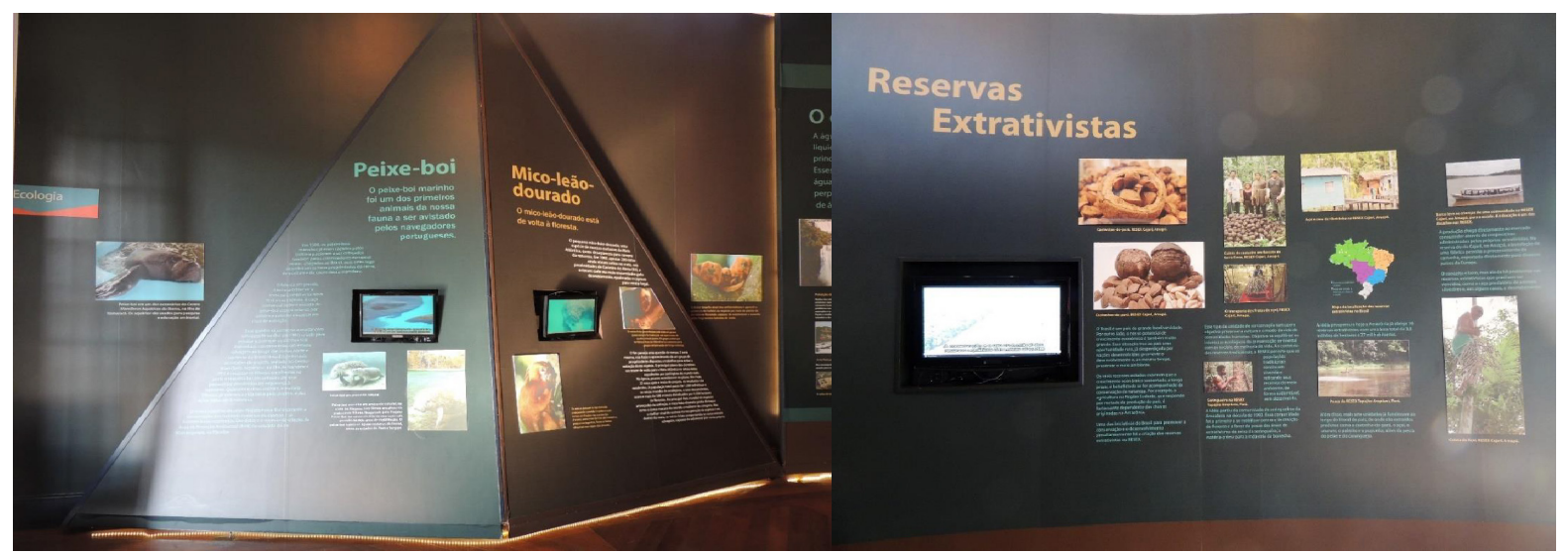

Figura 6: Painel Peixe-boi/Mico-leão / Figura 7: Painel Reservas Extrativistas

Fonte: Arlete Higashi, jun. 2016

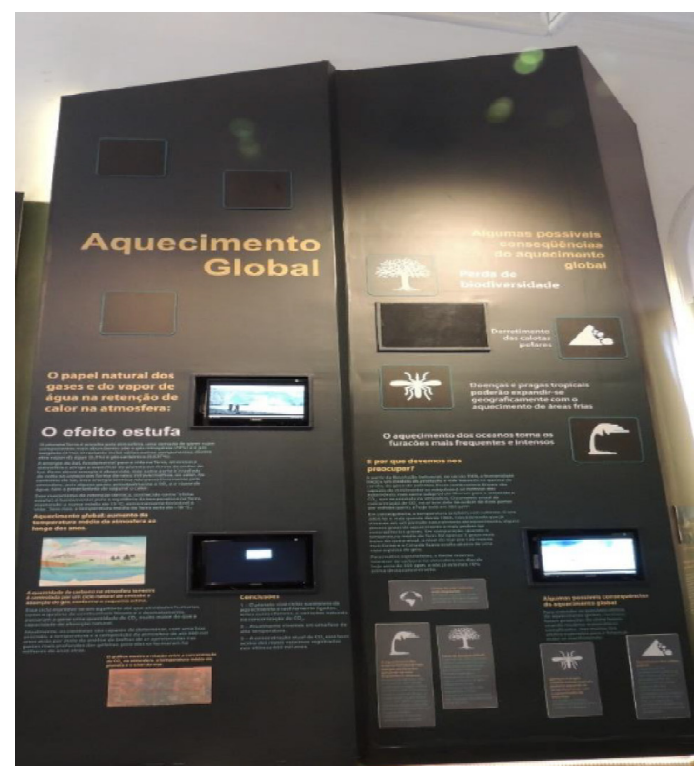

Figura 8: Painel Aquecimento Global

Fonte: Arlete Higashi, jun. 2016

Esses recursos expositivos são comumente encontrados nos gêneros de divulgação científica, sejam direcionados para o público não-especialista, sejam para os

HIGASHI, A. M. F. 0 destinatário-visitante presumido nas exposiç̦oes de divulgação científica do Catavento Cultural 
pares. Sua compreensão exige um certo grau de letramento 4 do destinatário-visitante presumido, no sentido de que ele tenha, entre outras, a habilidade de fazer as conexões necessárias entre as informações do texto verbal e as do texto visual.

Em síntese, semelhante à Corpo Humano, a estrutura composicional da exposição Ecologia é o elemento que mais inscreve o destinatário-visitante, visto que se organiza de modo a captar, primeiramente, a atenção do seu interlocutor. Para tanto, distribui-se em um corredor, que dá passagens a outras subseções da seção Sociedade. Além disso, a Ecologia também se apresenta em painéis de grandes proporções, os quais despertam a atenção de quem passa. No entanto, em relação aos outros elementos, estilo e conteúdo temático, constatamos que a construção do enunciado foi afetada basicamente pela entonação avaliativa do falante acerca do seu objeto, o que contribuiu para a construção de um discurso ideológico, com viés nacionalista, aliado à valoração do empenho dos cientistas ou do campo da ciência. Conforme verificado acima, tais aspectos se materializaram, principalmente, nas escolhas lexicais do enunciado expositivo que, além de colocarem em relevo os conhecimentos científicos, refletiram os gostos sociais e o tom expressivo do locutor. Contudo, também destacamos que, como bem afirmou Bakhtin (2016[1952], p. 130), "nos momentos crucias sempre se intensifica o elemento dialógico do discurso, agudiza-se a sensação de ouvinte-contemporâneo, inimigo ou amigo", o qual, na exposição Ecologia, é representado nas dimensões verbal e visual do painel $O$ que podemos fazer, onde podemos identificar certa sensação do ouvinte presumido tantos nas escolhas lexicais quanto na seleção de imagens. Aqui, o destinatáriovisitante em potencial é um outro ativo-responsivo contemporâneo capaz de compreender e afetar a realidade apresentada na exposição.

4 Para Magda Soares (1998), letramento é [...] um estado, uma condição: o estado ou condição de quem interage com diferentes portadores de leitura e de escrita, com diferentes gêneros e tipos de leitura e de escrita, com as diferentes funções que a leitura e a escrita desempenham em nossa vida (p. 44).

HIGASHI, A. M. F. 0 destinatário-visitante presumido nas exposições de divulgação científica do Catavento Cultural 
Linha D'Água (Online), São Paulo, v. 33, n. 3, p. 221-246, set.-dez. 2020

\section{Considerações finais}

Este trabalho originou-se do pressuposto bakhtiniano de que todo e qualquer enunciado, em maior ou menor grau, é sempre direcionado, tem um destinatário, um outro, de quem espera uma atitude responsiva. Levando em conta, então, que todo discurso é dialógico, dirigido a um destinatário real ou hipotético, o objetivo principal deste trabalho foi verificar a quem os enunciados expositivos de divulgação científica do Catavento Cultural e Educacional são orientados.

Diante dessa imagem presumida, o falante/escrevente seleciona o conteúdo temático, o estilo e a construção composicional das exposições, nas quais inscreve seu interlocutor por meio de movimentos dialógicos, não apenas com vistas a divulgar os conhecimentos da ciência, mas também a exercer diferentes influências no destinatário-visitante: educativa; de conscientização ambiental; de valorização da esfera científica; de mudança de conduta; de avaliação e concordância em relação aos conhecimentos produzidos pela esfera científica.

No primeiro movimento, observamos que o enunciado se volta de modo direto para o destinatário-visitante hipotético e seu fundo de apercepção. Para demonstrar como isso ocorre, analisamos as materialidades verbais e visuais do conteúdo temático, da construção composicional e do estilo das exposições Corpo Humano, da seção Vida, salientando em que medida o destinatário presumido influencia na construção do enunciado expositivo. A partir da análise, depreendemos que o falante constrói seu discurso expositivo mediante a pressuposição de um visitantedestinatário da esfera do cotidiano interessado em assuntos que se relacionam a ele próprio: a composição do corpo humano, a manutenção e a saúde corporal e os efeitos dos estudos e descobertas sobre o DNA no meio social. Assim, o conteúdo temático foi concebido no enunciado mediante a imagem presumida desse interlocutor. Isso orientou também o modo de organização da exposição em blocos de textos e imagens explicativas e descritivas, e, acima de tudo, motivou o uso das seguintes escolhas estilísticas: meios linguísticos próprios dos textos falados; linguagem simples; metáforas; descrições; comparações e diferentes tipos de imagens que se relacionam, do ponto de vista temático, aos conhecimentos apresentados.

HIGASHI, A. M. F. 0 destinatário-visitante presumido nas exposições de divulgação científica do Catavento Cultural 
Por fim, no segundo movimento, a análise da exposição Ecologia mostrou que, mais uma vez, a forma composicional da exposição apresenta uma diretriz voltada para a captação do visitante-destinatário, haja vista que se distribui em painéis de grandes proporções, constituídos por textos, fotografias, tvs, mapas e gráficos, que estimulam a atenção de quem passa. Em relação aos outros elementos, estilo e conteúdo temático, identificamos que a seleção linguística, visual e o todo de sentido do enunciado foram afetados basicamente pela entonação avaliativa do autor acerca do seu objeto, o que contribuiu para a construção de um discurso ideológico, com viés nacionalista, aliado à valoração do empenho dos cientistas ou do campo da ciência. Conforme verificado na análise, tais aspectos se materializaram, principalmente, nas escolhas lexicais do enunciado expositivo que, além de colocar em relevo os conhecimentos científicos, refletiram a avaliação social, o tom expressivo do locutor. Contudo, do nosso ponto de vista, veladamente, esses aspectos também estão voltados para imagem do destinatário-visitante, na medida em que o discurso ideológico de educação ambiental objetiva influenciar as suas ações posteriores. Diante disso, ao expor valorativamente a relação devastadora do homem com o meio ambiente e o esforço da ciência para amenizar os efeitos dessa relação, inscreve-se um destinatário, ao mesmo tempo, responsável tanto pela devastação quanto por sua recuperação/salvação futura. Tal direcionamento permeia todo o discurso expositivo, mas pode ser percebido de modo mais evidente no painel O que podemos fazer, no qual analisamos como se dá de modo mais agudo a sensação do ouvinte presumido tanto nas escolhas lexicais quanto na seleção de imagens.

Em síntese, como bem adiantou Bakhtin (2016[1952], p. 149), a orientação do enunciado em relação ao destinatário pode revelar-se de modo aberto no enunciado, "mas também pode não haver esse reflexo: nesse caso, sempre existem harmônicos dialógicos, ainda que seja difícil captá-los”. Assim, com graus e modos distintos, todos os elementos que constituem os discursos expositivos de divulgação científica do Catavento Cultural e Educacional estabelecem uma relação com o "discurso real ou possível do interlocutor-ouvinte-leitor. E essa relação com o enunciado do outro define dado enunciado, encontra nele um reflexo (reflexo do discurso do outro) obrigatório" (BAKHTIN, 2016[1952], p. 135). 
Linha D’Água (Online), São Paulo, v. 33, n. 3, p. 221-246, set.-dez. 2020

\section{Referências}

AMORIM. M. O pesquisador e seu outro: Bakhtin nas ciências humanas. São Paulo: Marsa Editora, 2001.

ASSOCIAÇÃO BRASILEIRA DE CENTROS E MUSEUS DE CIÊNCIA. Centros e museus de ciência do Brasil. Rio de Janeiro: UFRJ.FCC. Casa da Ciência; Fiocruz. Museu da Vida, 2015.

BAKHTIN, M. Problemas da poética de Dostoiérski. Tradução de Paulo Bezerra. 4. ed. Rio de Janeiro: Forense Universitária, 2008[1963].

BAKHTIN, M. Diálogo I. A questão do discurso dialógico. In: BAKHTIN, M. Os gêneros do discurso. Tradução de Paulo Bezerra. São Paulo: Editora 34, 2016[1950], p. 113-124.

BAKHTIN, M. Diálogo II. In: BAKHTIN, M. Os gêneros do discurso. Tradução de Paulo Bezerra. São Paulo: Editora 34, 2016[1952], p. 125-150.

BAKHTIN, M. O Problema do texto na linguística, na filologia e outras ciências humanas. In: BAKHTIN, M. Os gêneros do discurso. Tradução de Paulo Bezerra. São Paulo: Editora 34, 2016 [1959-1961], p. 71-107.

CASTILHO, A. T. Nova gramática do português brasileiro. São Paulo: Contexto, 2010.

CHELINI, M. J. E.; LOPES, S. G. B. de C. Textos em museus de ciências: discurso científico, didático ou de divulgação? In: BENCHETRIT, S. F.; BEZERRA, R. Z.; MAGALHÃES, A. M. (Orgs). Museus e Comunicação: exposição como objeto de estudo. Rio de Janeiro: Museu Histórico Nacional, 2010.

SOARES, M. Letramento: um tema em três gêneros. Belo horizonte: Autêntica, 1998.

STUDART, D. C.; ALMEIDA, A. M.; VALENTE, M. E. Pesquisa de público em museus: desenvolvimento e perspectivas. In: GOUVÊA, G., MARANDINO, M., LEAL. M.C (Orgs.). Educação e museu: a construção social do caráter educativo dos museus de ciência. Rio de Janeiro: Access, 2003, p. 129-157.

HIGASHI, A. M. F. 0 destinatário-visitante presumido nas exposições de divulgaç̃̃o científica do Catavento Cultural 
Linha D’Água (Online), São Paulo, v. 33, n. 3, p. 221-246, set.-dez. 2020

VOLOCHÍNOV, V. Marxismo e filosofia da linguagem: problemas fundamentais do método sociológico na ciência da linguagem. Tradução de Sheila Viera de Camargo Grillo e Ekaterina Vólkova Américo. São Paulo: Editora 34, 2017[1929].

VOLÓCHINOV, V. A palavra na vida e a palavra na poesia para uma poética sociológica. In: A palavra na vida e a palavra na poesia: ensaios, artigos, resenhas e poemas. Tradução de Sheila Grillo e Ekaterina Vólkova Américo. São Paulo: Editora 34, 2019[1926], p. 109-146.

VOLÓCHINOV, V. A construção do enunciado e outros ensaios. Tradução de Sheila Grillo e Ekaterina Vólkova Américo. São Paulo: Editora 34, 2019[1930], p. 255-305.

Recebido:19/05/2020.

Aprovado: 15/06/2020.

HIGASHI, A. M. F. 0 destinatário-visitante presumido nas exposiçōes de divulgação cientifica do Catavento Cultural 